\title{
ПСИХОЛОГІЧНІ ОСОБЛИВОСТІ РОЗВИТКУ ЕМОЦІЙНО-МОТИВАЦЙНОГО КОМПОНЕНТА СТРЕСОСТІЙКОСТІ СОЦІАЛЬНИХ ПРАЦІВНИКІВ РІЗНИХ ВІКОВИХ КАТЕГОРІЙ
}

\author{
Юлія Тептюк \\ аспірантка кафедри теоретичної та консультативної психології \\ Національний педагогічний університет імені М. П. Драгоманова \\ 01601, Україна, м. Київ, вул. Пирогова, 9 \\ yuliia.teptiuk@gmail.com, https://orcid.org/0000-0001-7347-415X
}

\begin{abstract}
Анотація
Соціальна робота є невід'ємною складовою суспільства будь-якої країни, яка спрямована на підтримку тих верств населення, які у певний період часу є нездатними до ефективної самостійної адаптації до умов суспільного життя. Надзвичайно важливим завданням $\epsilon$ системна підготовка висококваліфікованих соціальних працівників, які здатні підтримувати та розвивати власну стійкість до стресів, що забезпечує успішність виконання фахівцями соціальної сфери їх професійних обов'язків. Стресостійкість є системною динамічною властивістю, яка визначає здатність людини справлятися із багатьма стресогенними ситуаціями, активно їх змінювати чи пристосовуватись до них без шкоди для свого здоров'я та зберігати ефективність виконуваної діяльності. Отже, вона активізує емоційну, когнітивну та поведінкову сфери особистості, тому доцільним є дослідження не лише загального рівня стійкості до стресу, а й особливостей розвитку ії структурних компонентів. Метою статті $є$ емпіричне дослідження психологічних особливостей розвитку емоційно-мотиваційного компонента стресостійкості соціальних працівників різних вікових категорій. Отримані результати проведеного дослідження дали змогу визначити особливості розвитку конструктів емоційно-мотиваційного компонента стресостійкості у соціальних працівників різних вікових груп, а саме рівня тривожності, емоційної врівноваженості та змотивованості до успіху. Було виявлено, що з віком у фахівців соціальної сфери підвищується рівень тривожності й емоційної врівноваженості, й одночасно зменшується кількість досліджуваних 3 високим рівнем мотивації до успіху і мотивації уникнення невдач. Такі результати пояснюються погіршенням стану здоров'я, зокрема нервової системи, зниженням рівня активності й зменшенням амбіцій, а також розвитком рефлексії свого емоційного стану, набуттям навичок цілеспрямовано на нього впливати, досягненням оптимального рівня мотивації до успіху, що одночасно сприяє ефективному виконанню професійних завдань та економії власних ресурсів.
\end{abstract}

Ключові слова: стресостійкість, психологічна еластичність, емоційно-мотиваційний компонент, тривожність, емоційна врівноваженість, мотивація досягнення успіху, соціальні працівники.

\section{Вступ}

Однією із важливих компетентностей соціального працівника $є$ здатність ефективно функціонувати у складних ситуаціях, які часто трапляються у практиці соціальної роботи. Цей вид компетентності, яку А.М. Льовочкіна визначила як стресостійкість, сприяє 
підтримці функціональних резервів, збереженню ментального здоров'я, що підвищує продуктивність професійної діяльності (Льовочкіна, 2017).

Ототожнюючи такі поняття, як стресостійкість та психологічна еластичність, S. Maddi наголосив на тому, що процес іiі розвитку є суто індивідуальним та залежить від відсутності негативних Я-образів та нищівної самокритики, здатності людини свідомо керувати власною поведінкою у кожній ситуації, вміння справлятися із горем та долати різні психологічні перешкоди, спрямованості до досягнення фізичного здоров'я та оптимізму (Maddi, 2006). A. Masten звернула увагу на те, що розвиток психологічної еластичності чи стресостійкості залежить не лише від зовнішньої ситуації («Я маю») та стану людини на теперішній час («Я $€ »)$, але і від соціально набутих якостей, вмінь та навичок («Я можу»), тобто копінг-стратегій (Masten, 2001).

На сьогодні серед науковців не існує єдиного погляду на структуру стресостійкості особистості. Сучасні дослідники А.Я. Боднар і Н.Г. Макаренко, які розуміють стійкість до стресу як складну інтегральну властивість особистості, презентовану комплексом інтелектуальних, когнітивних, емоційних й особистісних якостей, виокремлюють ії два структурних компонента, а саме: когнітивно-інтелектуальний та емоційно-особистісний. До першого, на думку науковців, належать такі особистісні властивості: гнучкість мислення; абстрактність мислення; поленезалежність як глобальна домінуюча тенденція особистості орієнтуватись при вирішенні проблем на власний досвід, а не на інших; розвинені перцептивні здібності. Складовими емоційно-особистісного компонента стресостійкості вчені вважають емоційну стійкість, оптимізм, середній рівень особистісної тривожності, середній рівень агресивності та внутрішній локус контролю (Боднар \& Макаренко, 2013).

Г.М. Дубчак зауважила, що у вітчизняній психології розуміння структури стресостійкості опирається на традиційний підхід щодо визначення структури психіки, згідно з яким іiі компонентами є емоційний, когнітивний і поведінковий (Дубчак, 2018). Відповідно до теоретичної моделі стресу 3 врахуванням перцептивних і когнітивних процесів, автором якої був Р. Лазарус, головна роль у розвитку стресостійкості особистості належить оцінці стресової ситуації людиною, тобто визначення індивідуальної значущості різних елементів ситуації та власної спроможності людини до подолання стресу (Lazarus, 1998). Це означає, що спочатку людина завдяки когнітивним процесам здійснює рефлексивну діяльність щодо особливостей стресу та власних ресурсів для його подолання. Це, в свою чергу, викликає в неї певні емоції, що впливають на мотивацію щодо цілеспрямованого регулювання власної поведінки, спрямованої на боротьбу зі стресом. Отже, враховуючи послідовність особливостей психологічного реагування на стрес i, відповідно, розвиток стресостійкості особистості, за нашою позицією, доцільним у структурі стресостійкості першим розглядати когнітивний компонент, другим - емоційний, а третім поведінковий.

До конструктів емоційного компонента стресостійкості, на думку М.С. Кудінової, належить низький рівень тривожності (Кудінова, 2016). Якщо ситуативна тривожність $\epsilon$ нормальною реакцією людини на різноманітні стресори та слугує іï адаптації до нових умов, то така психологічна властивість, як особистісна тривожність, виявляється в постійній схильності до переживань тривоги в різних ситуаціях, що негативно впливає на ефективність професійної діяльності працівників соціальної сфери та значно знижує їх стресостійкість. Ю.В. Калашніков відзначив, що у фахівців з підвищеним рівнем тривожності, які надають соціальні послуги різним категоріям населення, тривога може з'являтися внаслідок наявності 
невирішених проблемних ситуацій, заблокованої активності, що не дає змоги знизити збудження (Калашніков, 2003). Такі ситуації виникають дуже часто, адже успішність виконання професійних завдань залежить не лише від дотримання нормативності та старанності соціального працівника, а і від його спільної роботи з клієнтом, який, у свою чергу, інколи немотивований до співпраці, невідповідально ставиться до своїх обов'язків, або не в змозі їх виконувати з інших причин. Особистісна тривожність може виявлятися як схильність людини сприймати загрозу своєму «Я» в ситуаціях невизначеності, які регулярно трапляються під час виконання професійних завдань працівниками соціальної сфери, що робить їх вразливими до дії стресорів та блокує їх активність.

Емоційний компонент стресостійкості конструює емоційна реакція людини на стресову ситуацію, зокрема здатність контролювати свій емоційний стан під час дії (або після) стресора. Деякі вчені до цього компонента структури стресостійкості зараховують емоційну стійкість. Так, Sander L. Koole звернула увагу на необхідність розмежовувати поняття «емоційна саморегуляція» та «емоційна чутливість» як протилежні, адже регуляція виступає процесом вимкнення емоцій за необхідності, а чутливість, навпаки, провокує їх появу (Koole, 2009). На нашу думку, низький рівень емоційності та повільна зміна емоцій $є$ недоцільною особистісною властивістю для представників професій типу «людина-людина», зокрема й соціальних працівників, адже їхня професійна діяльність, насамперед, пов'язана зі спілкуванням, яке, в свою чергу, вимагає високого рівня емпатійності та вміння свідомо «підлаштовуватись» до емоційного стану клієнтів. Тому вважаємо, що до структури стресостійкості фахівця соціальної сфери належить не емоційна стійкість, а саме врівноваженість як вміння свідомо регулювати свій емоційний стан залежно від ситуації.

Мотив можна розглядати як форму вияву емоційного процесу, адже мотивація - це певна емоція плюс спрямованість дії. На нашу думку, задля більш компактної і зрозумілої структури стресостійкості соціального працівника доцільно об’єднати описані вище два компонента в один: емоційно-мотиваційний, конструктами якого можуть виступити низька тривожність, емоційна врівноваженість та змотивованість до досягнення успіху. А.О. Реан здійснив вдалий опис особистості, яка одночасно є змотивованою на успіх і завдяки цьому стійкою до стресів. Вчений здійснив характеристику такої людини, як активної, ініціативної й цілеспрямованої щодо пошуку способів подолання труднощів. Вона здатна планувати свою діяльність у довгостроковій перспективі, підвищувати ії результативність в умовах дефіциту часу і без зовнішнього контролю (Реан, 2007). Отже, згадані вище особистісні якості, за нашою позицією, бажані для ефективності професійної діяльності соціального працівника, оскільки сприяють його стійкості до стресів, а тому змотивованість до успіху можна вважати конструктом мотиваційного компонента стресостійкості фахівців соціальної сфери.

Отже, емоційно-мотиваційний компонент стійкості до стресу працівників соціальної сфери базується на здатності долати емоційну напругу та свідомо регулювати власний емоційний стан і рівень тривожності, а також переважанні мотивації до успіху над мотивацією уникнення невдачі. Метою дослідження є емпіричне дослідження психологічних особливостей розвитку емоційно-мотиваційного компонента стресостійкості соціальних працівників різних вікових категорій. Завдання дослідження: 1) здійснити теоретичний аналіз особливостей емоційно-мотиваційного компонента стресостійкості соціальних працівників різних вікових категорій; 2) емпірично дослідити особливості розвитку 
конструктів емоційно-мотиваційного компонента стійкості до стресу соціальних працівників у періоди ранньої, середньої та пізньої дорослості.

\section{Методи дослідження}

3 метою комплексного емпіричного дослідження психологічних особливостей розвитку емоційно-мотиваційного компонента стресостійкості фахівців соціальної сфери різних вікових категорій було застосовано психодіагностичні методики, які визначають рівень сформованості та розвитку таких показників як рівень особистісної тривожності, емоційної врівноваженості та змотивованості до успіху.

3 метою вивчення такої психологічної властивості, як особистісна тривожність, було використано «Шкалу особистісної тривожності» (авт. Ч.Д. Спілбергер, адаптація Ю.Л. Ханіна) (Ханін, 1985). У загальному вигляді опитувальник Спілбергера-Ханіна містить дві шкали, які призначені для оцінки реактивної та особистісної тривожності. Для нашого дослідження ми використовували лише останню, оскільки нас цікавить тривожність не як психологічний стан, а як відносно стійка індивідуальна якість особистості. Обрана нами методика є дуже зручною та водночас інформативною, адже складається з 20-ти лаконічних тверджень, кожне з яких характеризує особливості прояву тривожності як індивідуального реагування на стрес, адже вона виникає у випадку, коли людина оцінює певну ситуацію як загрозливу для себе, що, в свою чергу, викликає певне хвилювання.

Для визначення рівня емоційної врівноваженості було застосовано методику «Емоційна збудливість - врівноваженість» (авт. Б.Н. Смірнов), яка містить 15 запитань і $\epsilon$ скороченою адаптованою версією методики «Дослідження психологічної структури темперамента» згаданого автора (Смірнов, 1989). Цей опитувальник дав змогу визначити наскільки вправно досліджувані вміють контролювати власні емоції у процесі діяльності або спілкування з іншими, стримувати негативні емоційні прояви у випадку незадоволення тих чи інших потреб, а також чи легко їм адаптуватися до соціального оточення.

3 метою визначення змотивованості до успіху соціальних працівників нами було використано методику «Мотивація успіху і боязкість невдачі» (авт. А.О. Реан) (Реан, 2007). Перевагою зазначеного опитувальника $є$ те, що він дає можливість визначити основний спонукальний мотив до різного виду діяльності досліджуваних - досягти успіху або уникнути можливої невдачі, що безпосередньо впливає на продуктивність цієї діяльності, та прояви наполегливості, цілеспрямованості, можливості доцільно планувати своє майбутнє.

Психодіагностичне дослідження стресостійкості соціальних працівників проводилось на базі 8-ми районних центрів соціальних служб для сімей, дітей та молоді та 9-ти районних територіальних центрів соціального обслуговування у м. Києві та Уманського районного центру соціальних служб для сімей, дітей і молоді, Уманського районного територіального центру соціального обслуговування та Управління праці та соціального захисту населення Уманської міської ради. Загальна кількість досліджуваних становила 177 осіб.

Для того, щоб був можливим аналіз і порівняння особливостей розвитку структурних компонентів стресостійкості в соціальних працівників різних вікових категорій, відповідно до вікової періодизації Г. Крайг, нами було сформовано три окремі групи досліджуваних: 60 осіб раннього дорослого віку (від 20-ти до 39-ти років), 60 осіб середнього дорослого віку (від 40-ка до 59-ти років) і 57 осіб віку старшої дорослості (від 60-ти років). 


\section{Результати та дискусії}

Як зазначено вище, одним із основних конструктів емоційно-мотиваційного компонента стресостійкості, що обумовлює особливості іiі розвитку в соціальних працівників, є рівень їхньої особистісної тривожності, яка має захисну (передбачення небезпеки і підготовка до неї) та мотиваційну (легка тривожність посилює мотивацію досягнення) функції. Тривожність - це емоційне особистісне утворення, певний рівень якої в нормі властивий всім людям і є необхідним для оптимального пристосування людини до дійсності.

В табл. 1 подано результати дослідження цього показника за допомогою методики діагностики самооцінки рівня тривожності Спілбергера-Ханіна (шкала особистісної тривожності).

Таблиия 1

\section{Кількісні показники особистісної тривожності соціальних працівників різного віку}

\begin{tabular}{|l|c|c|c|c|c|c|}
\hline & \multicolumn{2}{|c|}{$\begin{array}{c}\text { Високий } \\
\text { рівень }\end{array}$} & \multicolumn{2}{|c|}{$\begin{array}{c}\text { Середній } \\
\text { рівень }\end{array}$} & \multicolumn{2}{|c|}{$\begin{array}{c}\text { Низький } \\
\text { рівень }\end{array}$} \\
\cline { 2 - 8 } & $\mathrm{n}$ & $\%$ & $\mathrm{n}$ & $\%$ & $\mathrm{n}$ & $\%$ \\
\hline $\begin{array}{l}\text { Соціальні працівники віком від 20-ти до 39- } \\
\text { ти років (n=60) }\end{array}$ & 23 & 38,3 & 34 & 56,7 & 3 & 5,0 \\
\hline $\begin{array}{l}\text { Соціальні працівники віком від 40-ти до 59- } \\
\text { ти років (n=60) }\end{array}$ & 29 & 48,3 & 30 & 50,0 & 1 & 1,7 \\
\hline $\begin{array}{l}\text { Соціальні працівники віком старше 60-ти } \\
\text { років (n=57) }\end{array}$ & 42 & 73,7 & 12 & 21,0 & 3 & 5,3 \\
\hline
\end{tabular}

Високий рівень особистісної тривожності розглядається як дезадаптивна реакція, що виявляється у загальній дезорганізації поведінки особистості та іiі діяльності, особливо в ситуаціях оцінки іiі компетентності, та потребує зниження суб'єктивної значущості поставлених задач і перенесення акценту на осмислення змісту діяльності й формування почуття впевненості в успіху. Найменше досліджуваних з високим рівнем тривожності у наймолодшій віковій групі (38,3\%). Кількість соціальних працівників віком від 40-ка до 59ти років з середнім і високим рівнем тривожності майже однакова (50\% і 48,3\% відповідно). Переважна більшість $(73,7 \%)$ їх колег віку старшої дорослості характеризуються високим рівнем тривожності. Більш літні працівники, професійна діяльність яких пов'язана 3 наданням соціальних послуг різним категорія населення, значно частіше переживають, що не впораються з поставленими завданнями, відчувають невпевненість у власних можливостях подолати стресові ситуації, які можуть виникнути під час виконання їхніх професійних обов'язків, прогнозують менш позитивні наслідки різних складних робочих ситуацій тощо. Це може бути пов'язано з такими віковими фізіологічними особливостями, як погіршення загального стану здоров'я, зокрема нервової системи, зменшенням адаптивних можливостей досліджуваних, а також таким явищем, як емоційне вигорання.

Соціальні працівники віком від 20-ти років до 39-ти років характеризуються переважно середнім рівнем особистісної тривожності $(56,7 \%)$, що $є$ необхідним для ефективного пристосування до дійсності (адаптивна, мобілізуюча тривога). Аналогічний результат виявлено в половини $(50,0 \%)$ досліджуваних у період середньої дорослості та майже у чверті найстарших фахівців соціальної сфери $(21,0 \%)$. 
Низький рівень тривожності, який перешкоджає нормальній адаптації й заважає розвитку і продуктивній діяльності та потребує підвищення почуття відповідальності, зустрічається рідко у всіх вікових групах. Такий показник присутній у 5,0\% наймолодших досліджуваних, у 1,7\% соціальних працівників віком від 40-ка до 59-ти років та у 5,3\% фахівців старше 60-ти років. Це свідчить, що, незалежно від віку, більшість соціальних працівників добре адаптовані до професійної діяльності, вміють передбачати небезпечні ситуації та вчасно до них готуватися.

Тривожність, що $є$ схильністю людини до таких емоційних реакцій, як стан тривоги у відповідь на вплив загрозливих чинників, значно знижує адаптаційні можливості соціального працівника щодо подолання різноманітних стресових ситуацій, які можуть виникнути під час виконання ним професійних завдань. Порівняно 3 досліджуваними періоду ранньої дорослості, в яких тривожність може бути пов'язана з недостатнім життєвим і професійним досвідом поводження себе у незнайомих ситуаціях, фахівці соціальної сфери віком від 40-ка років і старше значно частіше характеризуються наявністю тривожності, як більш сталої особистісної якості, що вимагає корекції задля розвитку їхньої стресостійкості загалом.

Емоційна врівноваженість сприяє стресостійкості соціальних працівників, адже дає можливість контролювати негативні емоційні прояви навіть у стресогених ситуаціях, що, в свою чергу, дає можливість підтримувати необхідний рівень ефективності виконання професійної діяльності.

Кількісні показники цього конструкта емоційно-мотиваційного компонента стійкості до стресу фахівців соціальної сфери подано в табл. 2.

Таблиия 2

Кількісні показники емоційної врівноваженості соціальних працівників різного віку

\begin{tabular}{|l|c|c|c|c|c|c|}
\hline & \multicolumn{2}{|c}{$\begin{array}{c}\text { Високий } \\
\text { рівень }\end{array}$} & \multicolumn{2}{c|}{$\begin{array}{c}\text { Середній } \\
\text { рівень }\end{array}$} & \multicolumn{2}{c|}{$\begin{array}{c}\text { Низький } \\
\text { рівень }\end{array}$} \\
\cline { 2 - 9 } & $\mathrm{n}$ & $\%$ & $\mathrm{n}$ & $\%$ & $\mathrm{n}$ & $\%$ \\
\hline $\begin{array}{l}\text { Соціальні працівники віком від 20-ти до 39- } \\
\text { ти років (n=60) }\end{array}$ & 19 & 31,7 & 32 & 53,3 & 9 & 15,0 \\
\hline $\begin{array}{l}\text { Соціальні працівники віком від 40-ти до 59- } \\
\text { ти років (n=60) }\end{array}$ & 21 & 35,0 & 35 & 58,3 & 4 & 6,7 \\
\hline $\begin{array}{l}\text { Соціальні працівники віком старше 60-ти } \\
\text { років (n=57) }\end{array}$ & 26 & 45,6 & 25 & 43,9 & 6 & 10,5 \\
\hline
\end{tabular}

Високий рівень емоційної врівноваженості виявлено в майже третини $(31,7 \%)$ досліджуваних віком від 20-ти до 39-ти років, 35,0\% їхніх колег періоду середньої дорослості та 45,6\% найстарших соціальних працівників. Такі фахівці демонструють витриманість, терпіння, послідовність поведінки, навіть у стресових ситуаціях, завдяки чому легко адаптуються до будь-якого соціального середовища. Ці якості є вкрай важливими для роботи у соціальній сфері.

Більшість соціальних працівників характеризуються середнім рівнем емоційної врівноваженості. Він виявлений у 53,3\% наймолодших досліджуваних, 58,3\% фахівців віком від 40-ка до 59-ти років та 43,9\% їхніх колег у період пізньої дорослості. Такі соціальні працівники у більшості знайомих їм випадків вдало контролюють свій емоційний стан, підлаштовуються до незначних змін та рідко відчувають себе ніяково. Можуть бути особливі 
ситуації, у яких вони почуваються більш вразливими або відчувають більший дискомфорт, ніж зазвичай.

Низький рівень емоційної врівноваженості продемонстрували 15,0\% соціальних працівників віком від 20-ти до 39-ти років, 6,7\% їхніх колег у період середньої дорослості та 10,5\% найстарших фахівців соціальної сфери. Таких досліджуваних можна охарактеризувати як емоційно нестійких, занадто чутливих до несприятливих обставин, особливо критики 3 боку оточуючих. Вони проявляють закомплексованість, невпевненість у собі, безпорадність у стресових ситуацій. Також можливі прояви агресії. Такі соціальні працівники потребують багато часу для відновлення адекватного емоційного стану.

Отримані результати дослідження підтверджують думку G. Labouvie-Vief i M. Devoe, які звернули увагу на той факт, що дорослі люди з віком, завдяки набутому життєвому досвіду краще регулюють власні емоції, що допомагає їм бути стійкішими до стресових впливів. (Labouvie-Vief \& Devoe, 1991). Загалом можна зробити висновок, що з віком у фахівців соціальної сфери підвищується рівень емоційної врівноваженості, що пов'язано 3 розвитком рефлексії власного емоційного стану, набуттям навичок на нього цілеспрямовано впливати, позитивному досвіду боротьби зі стресом.

Мотивація до успіху, що є одним з основних конструктів емоційно-мотиваційного компонента стресостійкості соціальних працівників, полягає у тому, що змістовою основою активності особистості є потреба у досягненні успіху, в професійній діяльності зокрема.

Особливості прояву цього показника у фахівців соціальної сфери різного віку подано в табл. 3.

Таблиця 3

\section{Кількісні показники мотивації досягнення успіху соціальних працівників різних} вікових категорій

\begin{tabular}{|l|c|c|c|c|c|c|}
\hline & \multicolumn{2}{|c|}{$\begin{array}{c}\text { Мотивація } \\
\text { досягнення успіху }\end{array}$} & $\begin{array}{c}\text { Мотиваційний } \\
\text { полюс } \\
\text { невиражений }\end{array}$ & $\begin{array}{c}\text { Мотивація } \\
\text { уникнення невдач }\end{array}$ \\
\cline { 2 - 7 } & $\mathrm{n}$ & $\%$ & $\mathrm{n}$ & $\%$ & $\mathrm{n}$ & $\%$ \\
\hline $\begin{array}{l}\text { Соціальні працівники віком від } \\
\text { 20-ти до 39-ти років (n=60) }\end{array}$ & 26 & 43,3 & 16 & 26,7 & 18 & 30,0 \\
\hline $\begin{array}{l}\text { Соціальні працівники віком від } \\
\text { 40-ти до 59-ти років (n=60) }\end{array}$ & 22 & 36,7 & 27 & 45,0 & 11 & 18,3 \\
\hline $\begin{array}{l}\text { Соціальні працівники віком } \\
\text { старше 60-ти років (n=57) }\end{array}$ & 19 & 33,3 & 30 & 52,6 & 8 & 14,0 \\
\hline
\end{tabular}

Завдяки поданим у табл. 3 кількісним показникам можна помітити, що високий рівень мотивації до успіху спостерігається у 43,3\% досліджуваних наймолодшої вікової категорії, у $36,7 \%$ їхніх колег віком від 40-ка до 59-ти років та у третини $(33,3 \%)$ фахівців соціальної сфери у період пізньої дорослості. Такі соціальні працівники у професійній діяльності проявляють активність та ініціативність, завзято долають перешкоди на шляху до обраної мети. Продуктивність їхньої діяльності більшою мірою залежить від їхнього прагнення досягти позитивних результатів, а не від зовнішнього контролю. 
Середній рівень мотивації до успіху або, іншими словами, невиражений мотиваційний полюс, характеризує 26,7\% фахівців соціальної сфери віком від 20-ти до 39-ти років, 45,0\% досліджуваних у період середньої дорослості та більше половини $(52,6 \%)$ їхніх найстарших колег. Таких соціальних працівників можна описати як активних лише у випадках знайомих або середньої важкості ситуацій, коли ризик незначний. У зв’язку з цим, вони не схильні планувати своє майбутнє у довгостроковій перспективі. Досліджувані частіше надають перевагу виконанню завдань, які їм запропонували інші, а не виявляти ініціативу в самостійних пошуках нових завдань.

Майже у третини (30,0\%) наймолодших соціальних працівників спостерігається низький рівень мотивації до успіху, тобто їхня активність спрямована на уникнення невдач. Така ж ситуація і у $18,3 \%$ їхніх колег віком від 40-ка до 59-ти років та у 14,0\% їхніх старших колег. Ці соціальні працівники, зазвичай, шукають причини відмовитися від відповідальних завдань. При цьому, у випадку чергування успіхів та невдач, вони схильні переоцінювати власний успіх, що можна пояснити ефектом контролю очікування певного результату. Якщо у процесі виконання певної задачі трапляються труднощі, то в досліджуваних починає зникати до нього інтерес.

\section{Висновки}

Аналіз теоретичних джерел дав змогу визначити основні компоненти стресостійкості соціальних працівників, а саме: когнітивний, емоційний і поведінковий. Задля більш компактної і зрозумілої структури стійкості до стресу фахівців соціальної сфери ми об'єднати емоційний і мотиваційний в один: емоційно-мотиваційний, який базується на здатності долати емоційну напругу та свідомо регулювати власний емоційний стан і рівень тривожності, а також переважанні мотивації до успіху над мотивацією уникнення невдачі. Отже, конструктами емоційно-мотиваційного компонента стресостійкості соціальних працівників різних вікових категорій $€$ низька особистісна тривожність, емоційна врівноваженість і змотивованість до досягнення успіху.

Емпірично доведено, що, чим старші соціальні працівники, тим вищий рівень їх особистісної тривожності. Такі результати можна пояснити погіршенням стану здоров'я, зокрема і нервової системи, зменшенням адаптивних можливостей досліджуваних, а також таким явищем як емоційне вигорання. Також було виявлено, що з віком у фахівців соціальної сфери підвищується рівень емоційної врівноваженості, що пов'язано з розвитком рефлексії власного емоційного стану, набуттю навичок на нього цілеспрямовано впливати, позитивному досвіду боротьби зі стресом.

За результатами проведеного дослідження можна помітити дві протилежні тенденції. По-перше, 3 віком відбувається зниження мотивації до успіху, що можна пояснити зменшенням загальної активності особистості та зниженням амбіцій, а також накопиченням негативного досвіду неуспішного виконання професійних завдань. По-друге, чим старші соціальні працівники, тим менша їхня мотивація до уникнення невдач, що пов'язано зі зростанням професіоналізму. Тому можна зробити висновок, що з віком фахівці соціальної сфери досягають оптимального рівня мотивації до успіху, що одночасно сприяє ефективному виконанню професійних завдань й економії своїх ресурсів.

Практична значущість проведеного дослідження полягає в тому, що враховуючи особливості розвитку особистісних властивостей соціальних працівників у періоди ранньої, середньої та пізньої дорослості, які $€$ конструктами емоційно-мотиваційного компонента їхньої стресостійкості, можна ефективніше формувати соціально-психологічні тренінги щодо 
підвищення рівня стійкості до стресу, диференціюючи групи учасників за віком, в кожній 3 яких акцентувати увагу на розвитку тих якостей особистості, які потребують цього найбільше.

Перспективи подальших досліджень полягають у визначенні психологічних умов, що позитивно впливають на розвиток емоційно-мотиваційного компонента стресостійкості соціальних працівників різних вікових категорій.

\section{Література}

1. Боднар, А.Я., \& Макаренко, Н.Г. (2013). Психологічні особливості стресостійкості представників стресогенних професій (на прикладі працівників приватних охоронних структур). Наукові записки. Педагогічні, психологічні науки та соціальна робота, 149, 49-56.

2. Дубчак, Г.М. (2018). Психологія становлення професійної стресостійкості майбутніх фахівців соціономічних професій. (Дис. д-ра психол. наук). Київ.

3. Калашников, Ю.В. (2003). Как избежать самовыгорания. Соціальна робота в Украӥні: теорія і практика, 2, 186-191.

4. Кудінова, М.С. (2016). Порівняльний аналіз понять «стресостійкість» та «емоційна стійкість». Теорія і практика сучасної психологї, 1, 22-28.

5. Льовочкіна, А. (2017). Здатність діяти у стресових ситуаціях як професійна компетентність соціального працівника. Вісник Київського національного університету імені Тараса Шевченка. Соціальна робота, 2, 10-13.

6. Реан, А.А. (2007). Психология адаптациии личности. Санкт-Петербург : ПраймЕВРОЗНАК, 479.

7. Смирнов, Б.Н. (1989). Практические занятия по психологии. Москва.

8. Ханін, Ю.Л. (1985). Особистісні та соціально-психологічні опитувальники в прикладних дослідженнях: проблеми і перспективи. Соціальна психологія $і$ громадська практика, 163-177.

9. Koole, Sander L. (2009). «The psychology of emotion regulation: An integrative review». Cognition \& Emotion., 23(1), 4-41.

10. Labouvie-Vief, G., \& Devoe, M. (1991). Emotional regulation in adulthood and later life: A developmental review. Annual review of gerontology and geriatrics, 11, 172-194.

11. Lazarus, R.S., (1998). Fifty years of research and theory of R.S. Lazarus (An analyses of historical and perennial issues). New York : Psychology Press.

12. Maddi, S. (2006). Hardiness: The courage to grow from stress. The Journal of Positive Psychology, 1(3), 160-168.

13. Masten, A.S. (2001). Ordinary Magic. Resilience Processes in Development. American Psychologist, 56(3), 227-238.

\section{References}

1. Bodnar, A.Ia., \& Makarenko, N.H. (2013). Psykholohichni osoblyvosti stresostiikosti predstavnykiv stresohennykh profesii (na prykladi pratsivnykiv pryvatnykh okhoronnykh struktur). [Psychological features of stress resistance of representatives of stressful professions (on the example of employees of private security agencies)]. Naukovi zapysky. Pedahohichni, psykholohichni nauky ta sotsialna robota - Proceedings. Pedagogical, psychological sciences and social work, 149, 49-56 [in Ukrainian]. 
2. Dubchak, H.M. (2018). Psykholohiia stanovlennia profesiinoi stresostiikosti maibutnikh fakhivtsiv sotsionomichnykh profesii [Psychology of formation of professional stress resistance of future specialists of socionomic professions]. Doctor's thesis. Kyiv [in Ukrainian].

3. Kalashnykov, Yu.V. (2003). Kak yzbezhat samovyhoranyia. [How to avoid self-burnout]. Sotsialna robota v Ukraini: teoriia i praktyka - Social work in Ukraine: theory and practice, 2, 186-191 [in Russian].

4. Kudinova, M.S. (2016). Porivnialnyi analiz poniat «stresostiikist» ta «emotsiina stiikist». [Comparative analysis of the concepts of "stress resistance" and "emotional stability"]. Teoriia $i$ praktyka suchasnoi psykholohii - Theory and practice of modern psychology, 1, 22-28 [in Ukrainian].

5. Lovochkina, A. (2017). Zdatnist diiaty u stresovykh sytuatsiiakh yak profesiina kompetentnist sotsialnoho pratsivnyka. [Ability to act in stressful situations as a professional competence of a social worker]. Visnyk Kyivskoho natsionalnoho universytetu imeni Tarasa Shevchenka. Sotsialna robota - Bulletin of Taras Shevchenko National University of Kyiv. Social work, 2, 10-13 [in Ukrainian].

6. Rean, A.A. (2007). Psykholohyia adaptatsyy lychnosty. [Psychology of personality adaptation]. Saint Petersburg : Praim-EVROZNAK [in Russian].

7. Smyrnov, B.N. (1989). Praktycheskye zaniatyia po psykholohyy. [Practical training in psychology]. Moscow [in Russian].

8. Khanin, Yu.L. (1985). Osobystisni ta sotsialno-psykholohichni opytuvalnyky v prykladnykh doslidzhenniakh: problemy i perspektyvy. [Personality and socio-psychological questionnaires in applied research: problems and prospects]. Sotsialna psykholohiia i hromadska praktyka Social psychology and social practice, 163-177 [in Russian].

9. Koole, Sander L. (2009). «The psychology of emotion regulation: An integrative review». Cognition \& Emotion., 23(1), 4-41.

10. Labouvie-Vief, G., \& Devoe, M. (1991). Emotional regulation in adulthood and later life: A developmental review. Annual review of gerontology and geriatrics, 11, 172-194.

11. Lazarus, R.S., (1998). Fifty years of research and theory of R.S. Lazarus (An analyses of historical and perennial issues). New York : Psychology Press.

12. Maddi, S. (2006). Hardiness: The courage to grow from stress. The Journal of Positive Psychology, 1(3), 160-168.

13. Masten, A.S. (2001). Ordinary Magic. Resilience Processes in Development. American Psychologist, 56(3), 227-238. 


\title{
PSYCHOLOGICAL FEATURES OF THE DEVELOPMENT OF THE EMOTIONAL AND MOTIVATIONAL COMPONENT OF STRESS RESISTANCE OF SOCIAL WORKERS OF DIFFERENT AGE CATEGORIES Yuliia Teptiuk
}

Postgraduate Student of the Department of Theoretical and Counseling Psychology

National Pedagogical Dragomanov University

9, Pyrohov Str., Kyiv, Ukraine, 01601

yuliia.teptiuk@gmail.com, https://orcid.org/0000-0001-7347-415X

\begin{abstract}
Social work is an integral part of the society of any country, which is aimed at supporting those segments of the population who are unable to effectively adapt to the conditions of public life for a certain period of time. An extremely important task is the systematic training of highly qualified social workers who are able to maintain and develop their own resistance to stress, which ensures the success of social workers in their professional duties. Stress resistance is a systemic dynamic quality that determines a person's ability to cope with many stressful situations, actively change them or adapt to them without harm to their health, and maintain the effectiveness of their activities. Thus, it activates the emotional, cognitive and behavioral spheres of personality, so it is advisable to study not only the general level of resistance to stress, but also the peculiarities of the development of its structural components. The aim of the article is an empirical study of the psychological features of the development of the emotional and motivational component of stress resistance of social workers of different ages. The results of the study made it possible to determine the features of the development of constructs of the emotional-motivational component of stress resistance in social workers of different ages, the level of anxiety, emotional balance and motivation to succeed. It was found, that with age, social workers increase the level of anxiety and emotional balance, as well as reduce level of motivation to succeed and motivation to avoid failure. Such results can be explained by the deterioration of health, including the nervous system, decreased activity and reduced ambition, as well as the development of reflection of one's emotional state, the acquisition of skills to purposefully influence it, achieving optimal motivation to succeed, which also contributes to effective performance of professional tasks and saving of own resources.
\end{abstract}

Keywords: stress resistance, psychological resilience, emotional-motivational component, anxiety, emotional balance, motivation to succeed, social workers.

Подано 14.12.2020

Рекомендовано до друку 22.12.2020 